\section{Dental pain, socioeconomic status, and dental caries in young male adults from southern Brazil}

\author{
Dor de dente e sua relação com condições \\ sócio-econômicas e cárie dentária em adultos \\ jovens do sexo masculino no Sul do Brasil
}

\author{
1 Centro de Ciências da \\ Saúde, Universidade Federal \\ de Santa Catarina, \\ Florianópolis, Brasil. \\ Correspondence \\ M. A. Peres \\ Departamento de Saúde \\ Pública, Centro de Ciências \\ da Saúde, Universidade \\ Federal de Santa Catarina. \\ Campus Universitário - \\ Trindade, Florianópolis, SC \\ 88049-970, Brasil. \\ mperes@ccs.ufsc.br
}

\begin{abstract}
The aim of this study was to assess dental pain prevalence and its association with dental caries and socioeconomic status in 18-year-old males from Florianópolis, Santa Catarina, Brazil. A cross-sectional study was conducted in a random sample $(n=414)$ selected from the Brazilian Army conscription list in 2003. Dental pain during the 12 months prior to the interview was recorded as the outcome. Socioeconomic data were obtained through a questionnaire. Dental caries experience was registered according to the DMFT Index. Analyses included simple and multiple non-conditional logistic regression following a hierarchical approach. Response rate was $95.6 \%$. High rates of inter-examiner agreement were achieved (kappa > 0.83). Dental pain prevalence was $21.2 \%$ (95\%CI: 17.3-25.1). After adjustment, individuals with one or more untreated caries were 3.2 times more likely (95\%CI: 1.7-5.8) to have dental pain compared to caries-free subjects. Conscripts with low family income were 1.8 times more likely (95\%CI: 1.0-3.3) to have dental pain than those with higher income.
\end{abstract}

Toothache; Social Class; Risk Factors
João Luiz Dornelles Bastos 1

Lincon Hideo Nomura 1

Marco Aurélio Peres 1

\section{Introduction}

Few epidemiological studies of young adults have inquired about toothache in Brazil or elsewhere in the world. A MEDLINE bibliographic database search for the subject headings "tooth pain", "toothache", "dental pain", and "prevalence" in articles published from 1993 to March 2004 was performed. Four articles were retrieved by this search: two focused on children aged 8 to 10 years 1,2, one gathered information from adolescents aged 12, 14, 16, and 18 years 3 , and the last included adults 20 years and over 4 .

Most oro-facial pain has dental causes, namely toothache 5 , and such acute pain usually derives from oral conditions, specifically dental caries and periodontitis 1,6,7. However, it is known that pathological processes are not a necessary or sufficient cause of the phenomenon ${ }^{8}$. Thus, perception of pain can be modulated by cognitive factors such as knowledge, beliefs, and expectations, all being influenced by the social and cultural environments of affected individuals $8,9,10$.

Dental pain is less commonly reported by older as compared to younger persons 11 . Difference in reported tooth pain may be related to lower expectations for oral health later in life, so that a certain amount of pain is expected 12 . Fewer teeth at risk of pain could also explain this difference 11 .

The association between socioeconomic status and dental pain prevalence remains un- 
clear. Some studies point to a higher prevalence of dental pain among low socioeconomic groups $13,14,15$, while others indicate a lack of such association 16,17 .

It is argued that dental pain can affect quality of life 11, leading to sleep disorders, decreased work effectiveness, school absence, and avoidance of certain types of food 1,18,19. Dental pain has also been identified as a good predictor of restricted access to dental health services 20 as well as one important element for appropriate planning of oral health services 21 .

This study aimed to assess dental pain prevalence among 18-year-old males selected from the Brazilian Army conscription list in a southern Brazilian city in 2003. Associations between outcome and socioeconomic conditions were tested through a hierarchical approach.

\section{Methods}

A cross-sectional study was conducted among a total population of 3,735 male conscripts (18 years) at the 63rd Infantry Battalion in Florianópolis, Santa Catarina, southern Brazil, in 2003. Non-residents of Florianópolis and/or older conscripts were excluded.

The sample would require 350 individuals if the following parameters were adopted: unknown prevalence $(\mathrm{P}=50 \%)$, sample error of $5 \%$ (e $=0.05)$, and $95 \%$ confidence level $(\alpha=0.05)$ in a finite population $(3,735)$. As part of a larger project 22 , this study investigated dental pain prevalence in the same population group and took a sample of 414 subjects, which was deemed appropriate for the present study's purposes.

All subjects were called in for medical examination in August-September 2003. Nonclinical and clinical data were collected simultaneously. There was no recommended date or criterion for appearing for the examination, only a limit for each day according to a predefined number. Seventeen conscripts were randomly selected on each of the first 14 days and 16 each on the remaining 11 days.

The fieldwork team consisted of three previously calibrated examiners 23 . Kappa test was adopted in order to check for intra- and interexaminer reliability in dental caries diagnosis. One in every ten subjects was examined twice to test for intra- and inter-examiner agreement. Dental caries were measured through DMFT index 24 with natural light and sterilized plane mirrors, in respect to all measures of cross-in- fection control. Non-clinical data were collected through a socioeconomic questionnaire. Conscripts were not re-interviewed to test for reliability during the fieldwork.

Subjects were asked about dental pain experience through a single question, as follows: "Have you experienced toothache in the last twelve months?". Parents' and conscripts' schooling (measured in full years of study) as well as family income in the previous month, recorded in Brazilian currency (reals) and later converted to minimum wages ( 1 minimum wage $=$ approximately U\$80.00) were collected. Conscripts were also asked about their family size, existence and/or frequency of oral health-related behaviors (tooth brushing, flossing, and use of fluoridated dentifrice), and access to dental services, as well as lifetime dental consultations and dental consultation during the previous 12 months.

Data were processed and analyzed with SPSS 10.0 for Windows. Confidence intervals (95\%) were calculated for prevalence of dental pain and caries experience. Dental caries prevalence was assumed as the proportion of individuals with DMFT $>0$. DMFT descriptive statistics were also performed.

Relationships between outcome and independent variables were tested through bivariate analyses, estimation of odds ratio, and respective confidence intervals. Analyses were concluded by using non-conditional multiple logistic regression under a hierarchical approach (Figure 1).

Socioeconomic conditions were conceived as distal determinants (Figure 1, block 1). Parents' and conscripts' schooling were collected in attention to the following hypothesis: (i) individuals with more schooling are more likely to develop positive health-related behaviors and health status; (ii) higher educational level is commonly associated with higher income and better workplace and housing conditions; and (iii) health and schooling share some of the same determinants. Parents' schooling represented a more stable condition, which possibly influenced subjects' early childhood and life course. Conscripts' schooling may have played a role in later health status, modulating habits and oral health-related self-care. Analysis of family income data considered the hypothesis that income is strongly associated with material conditions: conscripts from more affluent families are more likely to live in good quality housing, enjoy more opportunities to develop 
Hierarchical model for data analyses and interpretation.

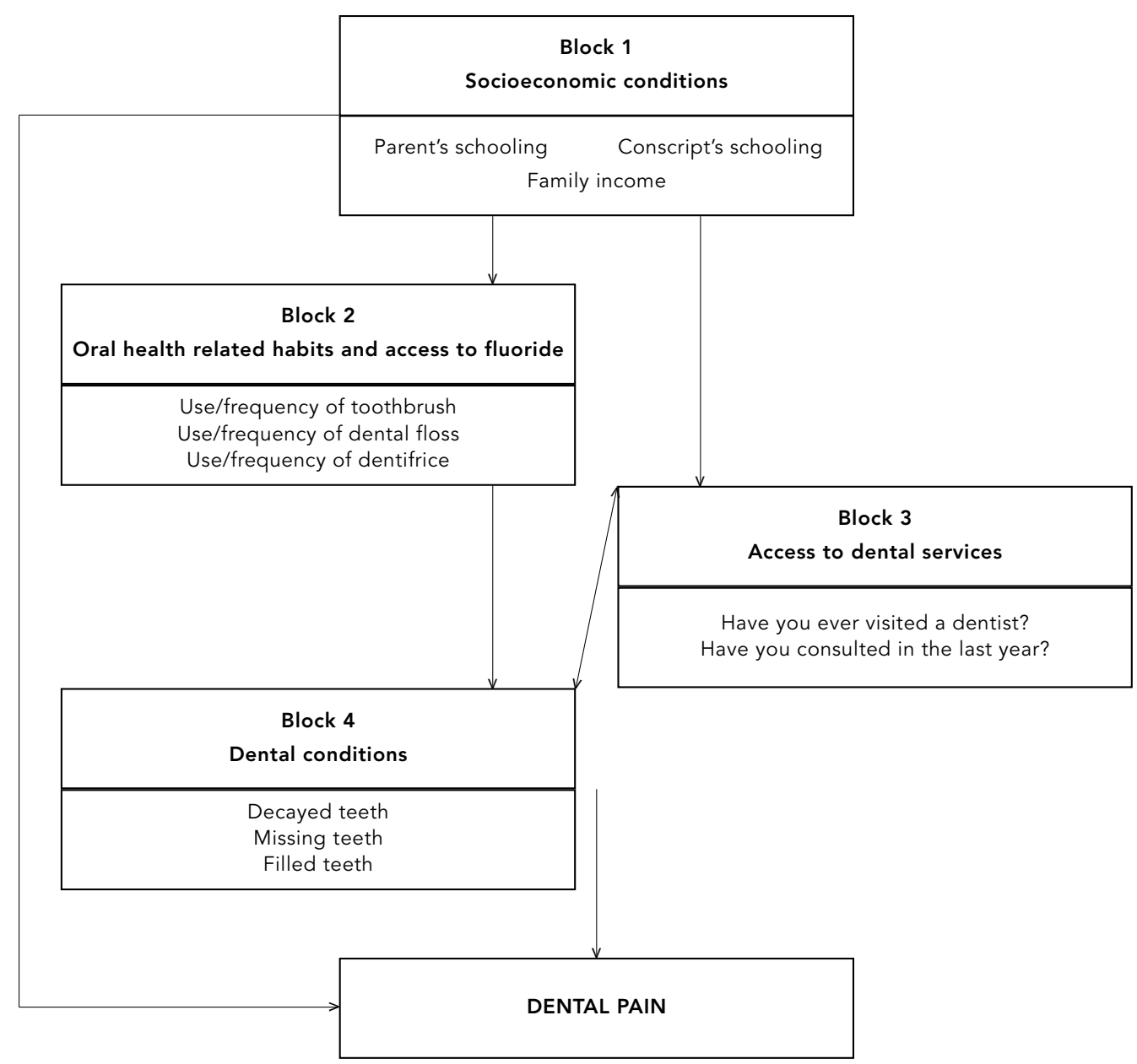

good oral health behavior, have access to a variety of oral hygiene items, and make healthy dietary choices.

Distal determinants are represented in Figure 1 (block 1). This block would directly or indirectly influence the remaining blocks, socalled mediating factors. Inside each block, stepwise backward procedure was performed to select the best predictors. Variables with $\mathrm{p}<0.25$ in bivariate analysis were included in the model. The level of statistical significance set in multivariate analysis (stepwise forward procedure) was 0.10 to remove variables from the model. Approval was obtained from the Institutional Review Board/ Research Ethics Committee of the Federal University in Santa Catarina.

\section{Results}

From a total of 414 conscripts, 18 refused to take part in the study (95.6\% response rate). The lowest kappa value on a tooth-by-tooth basis was 0.84 , but the vast majority of values were equal to 1.00 .

Dental caries status in this population was assessed in 199925 and later in 2003. Mean DMFT index was 3.3 (95\%CI: 2.9-3.6) and the decayed component (D) reached 1.8 (95\%CI: 1.5-2.0). Mean filled (F) teeth was 1.2 (95\%CI: 1.0-1.4), followed by missing component (M) with 0.3 (95\%CI: 0.2-0.4). Caries prevalence was 65.9\% (95\%CI: 62.9-68.9), while dental pain prevalence was $21.2 \%$ (95\%CI: 17.3-25.1).

Mean family income was $\mathrm{R} \$ 618.10$ (approximately U\$206.00) per month. Mean conscripts' 
schooling was 10.4 years, while parents' mean schooling was 10.0 years for fathers and 9.4 for mothers. Eighteen $(4.5 \%)$ young males reported no lifetime contact with any kind of dental services.

The first two steps of data analyses were to test the relationship between the outcome and independent variables through bivariate analyses and to select the best predictors of dental pain at each block through stepwise backward procedure (Table 1).
Stepwise backward procedure in Figure 1 (block 1) selected mothers' mean years of schooling ( $p=0.004)$, conscripts' mean years of study $(\mathrm{p}=0.035)$, and family income $(\mathrm{p}=0.037)$. In Figure 1 (block 2), flossing and frequency of flossing were selected as adjusting variables due to their distribution and statistical significance $(\mathrm{p}=0.112$ and $\mathrm{p}=0.127$, respectively). Brushing, frequency of brushing, and use of fluoridated dentifrice were excluded from the analysis, since they were not adequately dis-

Association between dental pain experience and socioeconomic conditions, behavioral aspects, access to dental services, and caries in 18-year-old males $(n=396)$ from Florianópolis, Santa Catarina, southern Brazil, 2003.

\begin{tabular}{|c|c|c|c|c|c|c|c|c|}
\hline \multirow[t]{3}{*}{ Variables } & \multicolumn{4}{|c|}{ Dental pain } & \multirow[t]{3}{*}{ crude OR } & \multirow[t]{3}{*}{$95 \% \mathrm{Cl}$} & \multirow[t]{3}{*}{ adjusted $O R^{\star}$} & \multirow[t]{3}{*}{$95 \% \mathrm{Cl}$} \\
\hline & \multicolumn{2}{|c|}{ Yes } & \multicolumn{2}{|c|}{ No } & & & & \\
\hline & $n$ & $\%$ & $n$ & $\%$ & & & & \\
\hline \multicolumn{9}{|c|}{$\begin{array}{l}\text { Socioeconomic conditions } \\
\text { (Figure 1, block } 1 \text { ) }\end{array}$} \\
\hline \multicolumn{9}{|c|}{ Father's schooling (years) ** } \\
\hline$>8$ & 23 & 12.1 & 167 & 87.9 & 1.0 & & & \\
\hline$\leq 8$ & 54 & 31.8 & 116 & 68.2 & 3.4 & $2.0-5.8$ & & \\
\hline $\mathbf{p}$ & & & & & $<0.001$ & & & \\
\hline \multicolumn{9}{|c|}{ Mother's schooling (years) } \\
\hline$>8$ & 26 & 12.4 & 184 & 87.6 & 1.0 & & 1.0 & \\
\hline$\leq 8$ & 58 & 31.2 & 128 & 68.8 & 3.2 & $1.9-5.4$ & 2.4 & $1.3-4.2$ \\
\hline $\mathbf{p}$ & & & & & $<0.001$ & & 0.004 & \\
\hline \multicolumn{9}{|c|}{ Conscript's schooling (years) } \\
\hline$>8$ & 60 & 18.2 & 269 & 81.8 & 1.0 & & 1.0 & \\
\hline$\leq 8$ & 24 & 35.8 & 43 & 64.2 & 2.5 & $1.4-4.4$ & 2.0 & $1.1-4.0$ \\
\hline $\mathbf{p}$ & & & & & 0.002 & & 0.035 & \\
\hline \multicolumn{9}{|c|}{ Family income (MW) } \\
\hline$\geq 6$ & 25 & 12.6 & 173 & 87.4 & 1.0 & & 1.0 & \\
\hline$<6$ & 59 & 29.8 & 139 & 70.2 & 3.0 & $1.7-5.0$ & 1.8 & $1.0-3.3$ \\
\hline $\mathrm{p}$ & & & & & $<0.001$ & & 0.037 & \\
\hline \multicolumn{9}{|c|}{ Oral hygiene (Figure 1, block 2) } \\
\hline \multicolumn{9}{|c|}{ Do you brush your teeth? } \\
\hline Yes & 84 & 21.3 & 310 & 78.6 & 1.0 & & & \\
\hline No & - & - & 2 & 100.0 & 0.2 & $0.0-2.7$ & & \\
\hline $\mathbf{p}$ & & & & & 0.684 & & & \\
\hline \multicolumn{9}{|c|}{ Frequency of brushing } \\
\hline$\geq 2 /$ day & 83 & 22.4 & 287 & 77.6 & 1.0 & & & \\
\hline$<2 /$ day & 1 & 3.8 & 25 & 96.2 & 0.1 & $0.2-1.0$ & & \\
\hline $\mathbf{P}$ & & & & & 0.054 & & & \\
\hline \multicolumn{9}{|l|}{ Flossing } \\
\hline Yes & 26 & 17.8 & 126 & 82.9 & 1.0 & & 1.0 & \\
\hline No & 58 & 23.9 & 186 & 76.1 & 1.5 & $0.9-2.5$ & 1.5 & $0.9-2.5$ \\
\hline$p$ & & & & & 0.112 & & 0.112 & \\
\hline
\end{tabular}

(continues) 
Table 1 (continued)

\begin{tabular}{|c|c|c|c|c|c|c|c|c|}
\hline \multirow[t]{3}{*}{ Variables } & \multicolumn{4}{|c|}{ Dental pain } & \multirow[t]{3}{*}{ crude OR } & \multirow[t]{3}{*}{$95 \% \mathrm{Cl}$} & \multirow[t]{3}{*}{ adjusted $O R^{\star}$} & \multirow[t]{3}{*}{$95 \% \mathrm{Cl}$} \\
\hline & \multicolumn{2}{|c|}{ Yes } & \multicolumn{2}{|c|}{ No } & & & & \\
\hline & $n$ & $\%$ & $\mathrm{n}$ & $\%$ & & & & \\
\hline \multicolumn{9}{|c|}{ Frequency of flossing } \\
\hline$\geq 1 /$ day & 27 & 17.3 & 129 & 82.7 & 1.0 & & 1.0 & \\
\hline$<1 /$ day & 57 & 23.7 & 183 & 76.3 & 1.5 & $0.9-2.5$ & 1.5 & $0.9-2.5$ \\
\hline $\mathrm{p}$ & & & & & 0.127 & & 0.127 & \\
\hline \multicolumn{9}{|c|}{ Fluoridated dentifrice? } \\
\hline Yes & 84 & 21.3 & 310 & 78.7 & 1.0 & & & \\
\hline No & - & - & 2 & 100.0 & 0.2 & $0.0-2.7$ & & \\
\hline p & & & & & 0.684 & & & \\
\hline \multicolumn{9}{|c|}{$\begin{array}{l}\text { Access to dental service } \\
\text { (Figure 1, block } 3 \text { ) }\end{array}$} \\
\hline \multicolumn{9}{|c|}{ Have you ever visited a dentist? } \\
\hline Yes & 76 & 20.1 & 302 & 79.9 & 1.0 & & 1.0 & \\
\hline No & 8 & 44.4 & 10 & 55.6 & 3.2 & $1.2-8.3$ & 3.2 & $1.2-8.3$ \\
\hline $\mathbf{p}$ & & & & & 0.019 & & 0.019 & \\
\hline \multicolumn{9}{|c|}{$\begin{array}{l}\text { Did you visit your dentist } \\
\text { in the last } 12 \text { months? }\end{array}$} \\
\hline Yes & 54 & 53.2 & 179 & 76.8 & 1.0 & & & \\
\hline No & 30 & 18.4 & 133 & 81.6 & 0.7 & $0.4-1.2$ & & \\
\hline $\mathbf{p}$ & & & & & 0.254 & & & \\
\hline \multicolumn{9}{|c|}{ Caries attack (Figure 1, block 4) } \\
\hline \multicolumn{9}{|c|}{ DMFT Index } \\
\hline 0 & 13 & 9.6 & 122 & 90.4 & 1.0 & & & \\
\hline$\geq 1$ & 71 & 27.2 & 190 & 72.8 & 3.5 & $1.9-6.6$ & & \\
\hline $\mathbf{p}$ & & & & & $<0.001$ & & & \\
\hline \multicolumn{9}{|c|}{ D (decayed) component } \\
\hline 0 & 29 & 11.5 & 224 & 88.5 & 1.0 & & 1.0 & \\
\hline$\geq 1$ & 55 & 38.5 & 88 & 61.5 & 4.8 & $2.9-8.0$ & 4.2 & $2.5-7.2$ \\
\hline $\mathrm{p}$ & & & & & $<0.001$ & & $<0.001$ & \\
\hline \multicolumn{9}{|c|}{$M$ (missing) component } \\
\hline 0 & 62 & 18.2 & 279 & 81.8 & 1.0 & & 1.0 & \\
\hline$\geq 1$ & 22 & 40.0 & 33 & 60.0 & 3.0 & $1.6-5.5$ & 2.0 & $1.0-3.8$ \\
\hline$p$ & & & & & $<0.001$ & & 0.045 & \\
\hline \multicolumn{9}{|c|}{ F (filled) component } \\
\hline 0 & 37 & 17.9 & 167 & 82.1 & 1.0 & & & \\
\hline$\geq 1$ & 47 & 24.5 & 145 & 75.5 & 1.4 & $0.9-2.4$ & & \\
\hline$p$ & & & & & 0.124 & & & \\
\hline
\end{tabular}

* adjusted OR: adjusted by stepwise backward procedure in order to select the best predictors at each block; ** not available for 36 individuals.

$\mathrm{MW}=$ minimum wages.

tributed among participants. In Figure 1 (block $3)$, no contact with dental services was identified ( $p=0.019$ ). Finally, in Figure 1 (block 4 ), only D and $\mathrm{M}$ components maintained statistical significance $(\mathrm{p}<0.001$ and $\mathrm{p}=0.045$, respectively). DMFT index and F component showed $\mathrm{p}>0.25$.

The last step was to enter the best predictors from Figure 1 (blocks 1, 2, 3, and 4) in stepwise forward procedure, following the hierar- chical approach. After adjusting for socioeconomic variables, flossing, and frequency of flossing lost statistical significance $(\mathrm{p}=0.747$ and $\mathrm{p}=0.921$ ) and were removed. No contact with dental services also lost statistical significance $(p=0.224)$. D component remained associated with dental pain even after adjusting, but lost magnitude $(\mathrm{OR}=4.3$ to $\mathrm{OR}=3.2)$. $\mathrm{M}$ component lost statistical significance but remained in the model $(\mathrm{p}=0.094)$ (Table 2$)$. 
Stepwise logistic regression under hierarchical approach for the association between dental pain and risk factors in 18-year-old males $(n=396)$ from Florianópolis, Santa Catarina, southern Brazil, 2003.

\begin{tabular}{|c|c|c|c|c|}
\hline Variables & crude OR & $95 \% \mathrm{Cl}$ & adjusted $O R^{\star}$ & $95 \% \mathrm{Cl}$ \\
\hline \multicolumn{5}{|c|}{$\begin{array}{l}\text { Socioeconomic conditions } \\
\text { (Figure 1, block 1) }\end{array}$} \\
\hline \multicolumn{5}{|c|}{ Mother's schooling (years) } \\
\hline$>8$ & 1.0 & & & \\
\hline$\leq 8$ & 2.4 & $1.3-4.2$ & & \\
\hline$p$ & 0.004 & & & \\
\hline \multicolumn{5}{|c|}{ Conscript's schooling (years) } \\
\hline$>8$ & 1.0 & & & \\
\hline$\leq 8$ & 2.0 & $1.1-4.0$ & & \\
\hline p & 0.035 & & & \\
\hline \multicolumn{5}{|c|}{ Family income (MW) } \\
\hline$\geq 6$ & 1.0 & & & \\
\hline$<6$ & 1.8 & $1.0-3.3$ & & \\
\hline$p$ & 0.037 & & & \\
\hline \multicolumn{5}{|c|}{ Caries attack (Figure 1, block 4) } \\
\hline \multicolumn{5}{|c|}{ D (decayed) component } \\
\hline 0 & 1.0 & & 1.0 & \\
\hline$\geq 1$ & 4.2 & $2.5-7.2$ & 3.2 & $1.7-5.8$ \\
\hline$p$ & $<0.001$ & & $<0.001$ & \\
\hline \multicolumn{5}{|c|}{$M$ (missing) component } \\
\hline 0 & 1.0 & & 1.0 & \\
\hline$\geq 1$ & 2.0 & $1.0-3.8$ & 1.7 & $0.9-3.4$ \\
\hline $\mathrm{p}$ & 0.045 & & 0.094 & \\
\hline
\end{tabular}

* adjusted by socioeconomic conditions.

$\mathrm{MW}=$ minimum wages (referent to September 2003).

\section{Discussion}

Dental pain prevalence during the previous 12 months was $21.2 \%$ (95\%CI: 17.3-25.1). Similar results were found in Toronto, Canada, where dental pain prevalence reported in the previous four weeks was $18.0 \%$ among 14 -20-yearolds of both sexes 26. Another survey in Ontario showed $13.0 \%$ for 12-19-year-old males and females 27 . Research in a representative sample in the United States found a dental pain prevalence of $12.2 \%$ in adults ( $\geq 18$ years) 16 .

The authors from Toronto 26 showed similar results to those of the current study, even though different time periods were adopted (1and 12-month intervals, respectively). Sociocultural disparities may have impacted the reporting of dental pain, leading to concordant prevalence rates in studies with diverse study periods. Methodological discrepancies in data collection and analysis may also have accounted for lower comparability. After all, these stud- ies did not focus on populations equally distributed according to age and gender.

The instrument's inaccuracy stands out as a limitation in the current study. Clinical conditions such as tooth eruption (third molar), sensitivity of exposed dentine (temperature sensitivity), and different types of oro-facial pain may have been included in the reporting of dental pain, thus overestimating it. The utilization of more specific data collection instruments and examination and control of other clinical conditions (as mentioned above) could improve study validity. Absence of data on women's selfreported dental pain could also introduce bias, since they hypothetically attend health services more regularly and tend to report some types of oro-facial pain more frequently. On the other hand, high response rates (nearly 96.0\%) and high inter- and intra-examiner agreements (minimum kappa value of 0.84 ) reinforce the internal validity of this study. Likewise, data on self-reported symptoms are easily gathered in 
community studies and should be used more extensively.

Low family income and low mother's and conscript's schooling were associated with dental pain prevalence, in agreement with other studies 13,14,15. D component was also associated with dental pain after adjustment, indicating that untreated dental caries and their severe and cumulative consequences still require more adequate approaches and interventions to reduce and/or control them. According to previous observations, unless pain is unbearable, patients tend to postpone dental treatment for two weeks in most cases 7 . Those experiencing high levels of dental anxiety are among those with the poorest oral health-related quality of life 28 , which partially explains this finding. As reported in another study, lower-income individuals had worse oral conditions and were more likely to endure pain than their counterparts 4 . This suggests differences in access to services and possibly variable pain thresholds according to socioeconomic status.

\section{Resumo}

Nesse estudo, objetivou-se estimar a prevalência de dor de dente e testar sua associação com cárie dentária e condições sócio-econômicas em jovens de 18 anos do sexo masculino de Florianópolis, Santa Catarina, Brasil. Realizou-se estudo transversal em uma amostra aleatória $(n=414)$ de alistandos do Exército Brasileiro no ano de 2003. Dor de dente, relatada até 12 meses prévios à pesquisa, foi o desfecho investigado. Coletaram-se dados sócio-econômicos por meio de questionário. Cárie dentária foi aferida utilizando-se o indice CPOD. Utilizou-se análise de regressão logística múltipla não condicional, segundo um modelo hierárquico de determinação. A taxa de resposta foi de 95,6\%. Alta reprodutibilidade diagnóstica foi atingida (kappa > 0,83). A prevalência de dor de dente foi de $21,2 \%$ (IC95\%: 17,3-25,1). Após o ajuste entre as variáveis, identificou-se que jovens com um ou mais dentes cariados não tratados apresentaram uma chance 3,2 vezes maior (IC95\%: 1,7-5,8) de relatar dor de dente em relação aos livres de cárie não tratada. Jovens de famílias com baixa renda apresentaram chance 1,8 vez maior (IC95\%: 1,0-3,3) de acusarem dor em relação aos de maior renda.

Odontalgia; Classe Social; Fatores de Risco
Comparison of schooling and income characteristics in the study population and the overall Florianópolis population reinforces this study's external validity. Mean per capita family income was $\mathrm{R} \$ 618.12$ in this study, as compared to $\mathrm{R} \$ 701.42$ for the city as a whole 29 . Among conscripts' parents, $47.1 \%$ had less than eight years of schooling. Among individuals 25 years and over, $34.3 \%$ of Florianópolis residents had less than eight years of schooling 29.

Some important findings emerge from our analyses. First, dental pain prevalence affected one-fifth of the study population. Second, dental caries is one of the main causes of dental pain. Third, low family income and low mothers' and conscripts' schooling are associated factors with dental pain. Finally, services and strategies focusing on this population may not have been adequately applied, especially for those with worse socioeconomic and oral-health conditions.

\section{Contributors}

J. L. D. Bastos participated as principal author and was responsible for the study planning, clinical and non-clinical data collection, and assembling of the database, as well as collaborating in the data analysis and drafting the article. L. H. Nomura participated in the study planning, clinical and non-clinical data collection, assembling of the database, and critical review of the paper. M. A. Peres conceived and planned the study, analyzed the data, contributed to drafting of the paper, and conducted a critical review. 


\section{References}

1. Shepherd MA, Nadanovsky P, Sheiham A. The prevalence and impact of dental pain in 8-yearold school children in Harrow, England. Br Dent J 1999; 187:38-41.

2. Naidoo S, Chikle UM, Sheiham A. Prevalence and impact of dental pain in 8-10-year-olds in the Western Cape. SADJ 2001; 56:521-3.

3. Honkala E, Honkala S, Rimpelä A, Rimpelä M. The trend and risk factors of perceived toothache among Finnish adolescents from 1977 to 1997. J Dent Res 2001; 80:1823-7.

4. Vargas CM, Macek MD, Marcus SE. Sociodemographic correlates of tooth pain among adults: United States, 1989. Pain 2000; 85:87-92.

5. MacFarlane TV, Glenny AM, Worthington HV. Systematic review of population-based epidemiological studies of oro-facial pain. J Dent 2001; 29: 451-67.

6. Burgess J, Byers MR, Dworkin SF. Pain of dental and intraoral origin. In: Bonica JJ, editor. The Management of Pain. Philadelphia: Lea and Febiger; 1990. p. 746-58.

7. Gibson GB, Blasberg B, Hill SJ. A prospective survey of hospital ambulatory dental emergencies. Part 1: patient and emergency characteristics. Spec Care Dentist 1993; 13:61-5.

8. Sindet-Pedersen S, Petersen JK, Gotzsche PC. Incidence of pain conditions in dental practice in a Danish county. Community Dent Oral Epidemiol 1985; 13:244-6.

9. Dworkin SF, Chen ACN, Schubert MM, Clark DW. Cognitive modification of pain: information in combination with $\mathrm{N}_{2} \mathrm{O}$. Pain 2002; 19:339-46.

10. Eli I. Oral psychophysiology: stress, pain and behavior in dental care. Boca Raton: CRC Press; 1992.

11. Locker D, Grushka M. The impact of dental and facial pain. J Dent Res 1987; 66:1414-7.

12. Atchinson KA, Gift HC, Jack SS. Perceived oral health in a diverse sample. Adv Dent Res 1997; 11:272-80.

13. Carmichael C, French A, Rugg-Gunn A, Furness J. The relationship between social class and caries experience in five-year-old children in Newcastle and Northumberland after twelve years' fluoridation. Community Dent Health 1984; 1:47-54.

14. Evans DJ, Rugg GA, Tabari ED, Butler T. The effect of fluoridation and social class on caries experience in 5-year-old Newcastle children in 1994 compared with results over the previous 18 years. Community Dent Health 1996; 13:5-10.

15. Gilbert GH, Duncan R, Vogel WB. Six months of dental care use in dentate adults: six months use during a 24-month period in the Floridian Dental Care Study. Soc Sci Med 1998; 47:727-37.
16. Lipton JA, Ship JA, Larach-Robinson D. Estimated prevalence and distribution of reported orofacial pain in the United States. J Am Dent Assoc 1993; 124:115-21.

17. Richards W, Scourfield S. Oral ill-health in a general dental practice in South Wales. Prim Dent Care 1996; 3:6-13.

18. MacFarlane TV, Blinkhorn AS, Davies RM, Kincey J, Worthington HV. Oro-facial pain in the community: prevalence and associated impact. Community Dent Oral Epidemiol 2002; 30:52-60.

19. Slade GD. Epidemiology of dental pain and dental caries among children and adolescents. Community Dent Health 2001; 18:219-27.

20. Ekanayake L, Mendis R. Self reported use of dental services among employed adults in Sri Lanka. Int Dent J 2002; 52:151-5.

21. Sheiham A. A determinação de necessidades de tratamento odontológico: uma abordagem social. In: Pinto VG, organizador. Saúde bucal coletiva. São Paulo: Editora Santos; 2000. p. 223-42.

22. Traebert ESA. Impacto das oclusopatias na qualidade de vida de jovens do sexo masculino de 18 anos de idade de Florianópolis, SC [Dissertação de Mestrado]. Florianópolis: Universidade Federal de Santa Catarina; 2004.

23. Peres MA, Traebert J, Marcenes W. Calibração de examinadores para estudos epidemiológicos de cárie dentária. Cad Saúde Pública 2001; 17:153-9.

24. World Health Organization. Oral health surveys: basic methods. Geneva: World Health Organization; 1997.

25. Gonçalves ER, Peres MA, Marcenes W. Cárie dentária e condições sócio-econômicas: um estudo transversal com jovens de 18 anos de Florianópolis, Santa Catarina, Brasil. Cad Saúde Pública 2002; 18:699-706.

26. Clarke M, Locker D, Murray H, Payne B. The oral health of disadvantaged adolescents in North York, Ontario. Can J Public Health 1996; 4:261-3.

27. Locker D, Payne B. Inequalities in oral health: Ontarians aged 12 to 19 years. Toronto: Faculty of Dentistry, University of Toronto and Community Dental Services, North York Public Health Department; 1993. (Community Dental Health Services Research Unit; Health Measurement and Epidemiology Report No. 4).

28. McGrath C, Bedi R. The association between dental anxiety and oral health-related quality of life in Britain. Community Dent Oral Epidemiol 2004; 32:67-72.

29. Instituto Brasileiro de Geografia e Estatística. Contagem da população 2000. Rio de Janeiro: Instituto Brasileiro de Geografia e Estatística; 2001.

Submitted on 12/May/2004

Final version resubmitted on $05 /$ Oct $/ 2004$

Approved on 03/Dec/2004 